\title{
Aquifer Mapping in the Niger Delta Region: A Case Study of Edo State, Nigeria
}

\author{
Seghosime, A. ${ }^{1}{ }^{*}$, Ehiorobo, J.O. ${ }^{1}$, Izinyon, O.C. ${ }^{1}$ and Oriakhi, O. ${ }^{1}$ \\ ${ }^{1}$ Department of Civil Engineering, Faculty of Engineering, University of Benin, Benin City, Nigeria \\ Corresponding Author: *seghosime@gmail.com
}

\begin{abstract}
In Nigeria, potable water is in short supply to the greater population and where available, groundwater accounts for over $90 \%$ of the supply. Oil exploration and exploitation activities are carried out in the Niger Delta region of Nigeria and this has affected the environment in this region. However, naturally occurring traces of petroleum products in strata or petroleum losses through spillages can contaminate groundwater, thus aquifer mapping in the Niger Delta Region becomes crucial. The study involves collection, collation and analysis of relevant information and data required for successful development of groundwater in Edo state. Groundwater in Edo State occurs under different conditions in the various aquifers defined by the following geological units, namely: Coastal Plain Sands of the Benin Formation, Ogwashi- Asaba, Bende-Ameki and Imo Shale Group of the Tertiary Deposits, False-bedded Sandstones and the Nkporo Shale Group of the Cretaceous deposits and the Basement Complex Rocks which only contain groundwater in the overburden, faults and joints. From the information collated, groundwater levels are deepest in the Ishan Plateau where it is about 171 metres above mean sea level at Ekpoma. Away from the pleateau, groundwater rises southwards and northwards. At Aduwawa/lkpoba Hill (Benin City), the groundwater level is 40 metres, at Iguiye (Lagos Road, Benin City) to the west, the groundwater level is 55 metres and at Fugar to the north, the groundwater level is 95 metres. The groundwater flow direction is from the Plateau to all other areas with higher groundwater levels. Therefore, aquifer mapping in the Niger Delta region is necessary, as it will help in assessing the availability and development methods to be adopted.
\end{abstract}

Keywords: Groundwater, Aquifer, Borehole, Formation, Sediment, Niger Delta, Mapping

\subsection{Introduction}

As a result of rapid population growth and local development, potable water is in short supply and this has led to the resurgence of groundwater potentials for steady and reliable water (Alabi et al., 2010; Anomohanran, 2011a \& 2011b). Water in the zone of saturation is normally referred to as ground water and geology is therefore a controlling factor. Groundwater is very vital as it is a viable source of portable water for domestic use (Peter, 2013). An aquifer is a water saturated geologic unit that will yield water to well or spring at sufficient rate that can serve as practical source of water supply. It is therefore a water-bearing formation or ground water reservoir. In countries like Denmark, groundwater mapping is a high priority; the Danish government initiated the National Groundwater Mapping Programme to achieve a detailed description of Danish aquifers with respect to localization, extension, distribution and interconnection as well as vulnerability against contaminants (Stockmarr and Thomsen, 2012). Naturally occurring traces of petroleum products in strata (from which water is obtained) or petroleum losses through spillages can contaminate groundwater. This makes the aquifer mapping in the Niger Delta more significant as it is a region where oil exploration and exploitation activities are carried out.

A study on aquifer mapping and characterization in Anambra State indicated that Nanka formation in Anambra basin has a high level of groundwater potential (Emenike, 2001). Also, aquifer mapping in Onibode area, near Abeokuta South-West of Nigeria shows groundwater potentials (Oyedele, 2001). 
Therefore, the occurrence of groundwater is controlled by geology and hydrogeology; hence groundwater does not occur in desired quantities and qualities anywhere and everywhere (Kogbe, 1989). To successfully locate and drill a water borehole, the favourable conditions must be identified (Egbai, 2012; Peter, 2013; Egbai et al., 2015). This is achieved by the water explorer or hydrogeologist, employing a number of investigative tools. One of the direct tools includes procurement and analysis of existing geological and hydrogeological information and maps. In addition, subsurface information from existing borehole logs and pumping test data are required. The indirect tool involves the use of geophysical surveys, most often the electrical resistivity survey to identify subsurface features. Hence, it is necessary to continue to improve the data base for groundwater development in a country in order to be able to identify a stable and steady ground water sources for water supply. Therefore, this study will focus on aquifer mapping in the Niger Delta Region of Nigeria using Edo State as a case study.

\subsection{Materials and Methods}

\subsection{Study area}

Edo State lies between latitude $05^{\circ} 44^{\prime}$ to $07^{\circ} 34^{\prime} \mathrm{N}$ and longitude $05^{\circ} 04^{\prime}$ and $06^{\circ} 45^{\prime} \mathrm{E}$ and covers a land area of about 19,635 square kilometres (see Figure 1). The State is bounded to the East and South by Delta State, to the North by Kogi State and to the West by Ondo and Ekiti States. It is located within the rainforest zone of Nigeria with mean annual rainfall in the range of $1500 \mathrm{~mm}$ to $2500 \mathrm{~mm}$ and the mean monthly temperature varying from $25{ }^{\circ} \mathrm{C}$ to $28{ }^{\circ} \mathrm{C}$ (Benin Kingdom/Edo State Weather, 2018). Edo State is situated in a zone with relatively high rainfall. The State has two distinct seasons. These are the wet (rainy) season and the dry season. The rainy season occurs between the months of April and October with a short break in August. The dry season on the other hand lasts from October to April with dry harmattan winds between December and February, but with the effect of global warming and climate change, rains have been observed to fall irregularly almost in every month of the year. The terrain consists of hilly or dissected country in the north and dry flat country, around Benin City towards the South. There are also abundant fresh swamp waters flanking the main rivers, particularly the Niger. The highest elevations are at the dissected and hilly terrains in the north with heights of about $300 \mathrm{~m}$ and above such as the Igarra and Ososo hills in Edo North. Further south of this zone lies the dissected areas around Auchi and Okpella with elevations decreasing southwards to about 200-100 m down south to about $15 \mathrm{~m}$ above mean sea level. In the central region there is also the Ishan Plateau with elevation reaching about $350 \mathrm{~m}$ above sea level.

\subsection{Test methods}

The method used for the study included the following;

a) Field work which includes:

i. $\quad$ Geophysical survey using (Vertical Electrical Soundings, VES)

ii. Water borehole drilling.

b) Data Processing and Plotting of Groundwater contours.

\subsubsection{Electrical Resistivity Sounding (By Vertical Electrical Soundings)}

Groundwater exploration was carried out in four geological regions (Quaternary Sediments, Tertiary Sediments, Cretaceous Sediments and Basement Complex) and this was done using vertical electrical soundings (VES) method with the aid of ABEM SAS 300 Tetrameters and other field accessories. Geographical coordinates were obtained from Garmin Handheld GPS 72 receiver. The quantitative interpretations of the VES data acquired at the regions were done initially with the aid of the conventional partial curve matching technique subsequently fine-tuned with the aid of computer assisted iteration techniques. 


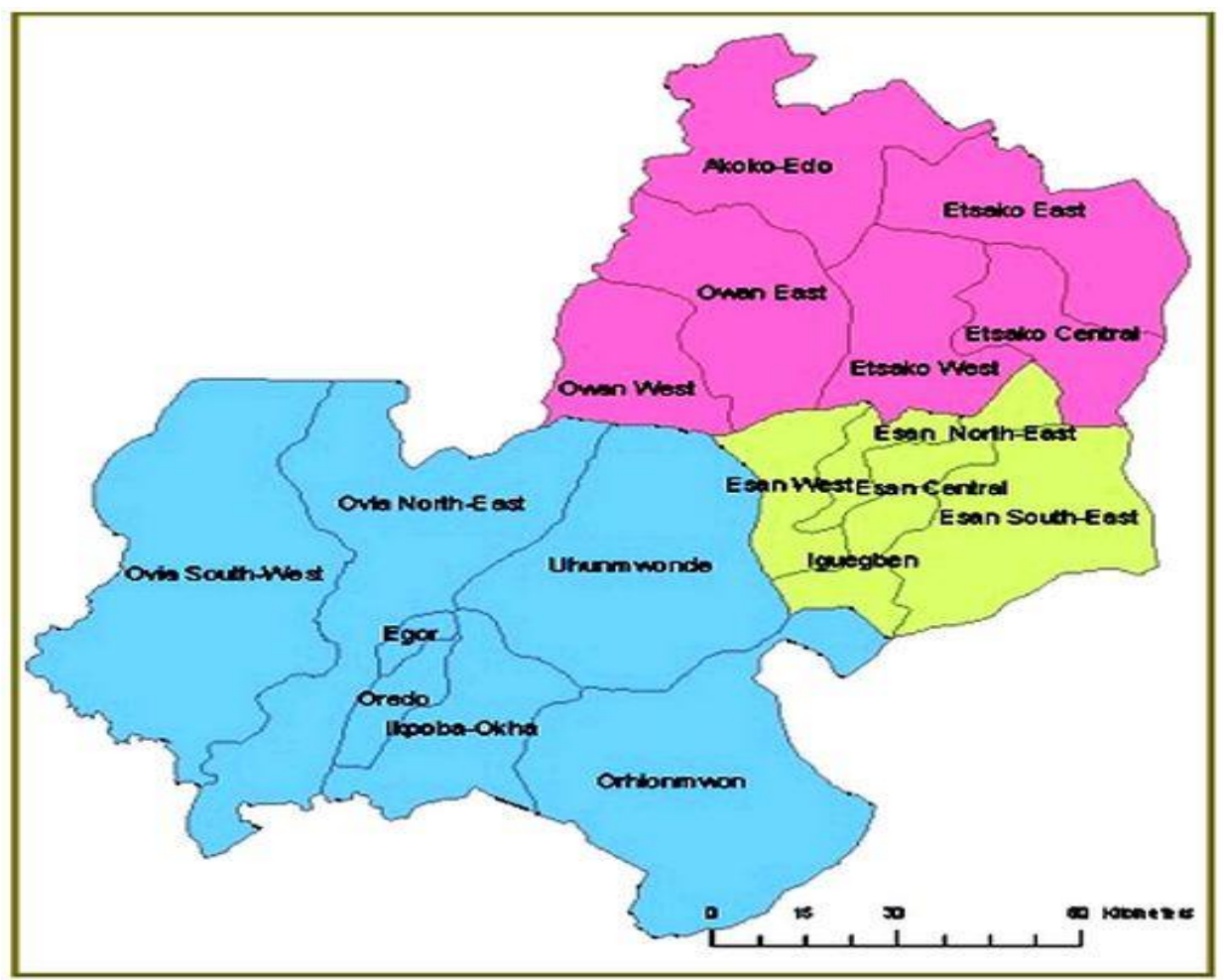

Figure 1: Map of Edo State

(Source: https://www.nigeriagalleria.com/Nigeria/States_Nigeria/Edo/Edo_State.html)

\subsubsection{Water borehole drilling}

Water boreholes were drilled in some selected area of Edo State to obtain boreholes data. The water borehole drilling involved drilling to a diameter of 8 inches using a water bore hole drilling rig (KW30). The drill's rotary machine (rotates at $30 \mathrm{rpm}$ to ensure straight borings) was powered with a hydraulic pump and then, compressed air drives to down-the-hole-hammer to pulverise the rock. Dust and cuttings were flushed out of the borehole by compressed air.

\subsubsection{Plotting of Groundwater Contours for Edo State}

Contours were plotted using the groundwater levels obtained from the water borehole data in some selected areas of Edo State. The water level at each location was determined and established with reference to the ground elevation.

\subsection{Results and Discussion}

Table 1 show the classification of groundwater regimes.

Table 1: Classification of groundwater regimes

\begin{tabular}{|l|l|l|l|}
\hline S/N & Region & Group & Nature of Aquifer \\
\hline 1 & Recent deposits & $\begin{array}{l}\text { Niger Alluvium, River } \\
\text { Alluvium }\end{array}$ & $\begin{array}{l}\text { Isolated minor sand lenses. Unimportant as } \\
\text { aquifer in Edo state }\end{array}$ \\
\hline 3 & Quaternary deposits & Benin formation & $\begin{array}{l}\text { Thick, unconsolidated sands with minor clays. } \\
\text { Highly permeable and productive aquifer }\end{array}$ \\
\hline 4 & Tertiary deposits & $\begin{array}{l}\text { (a) Ogwashi- Asaba } \\
\text { formation (lignite series) }\end{array}$ & $\begin{array}{l}\text { Thick fine to coarse grained sand with clays and } \\
\text { lignite. }\end{array}$ \\
\cline { 3 - 4 } & $\begin{array}{l}\text { (b) Bende- Ameki } \\
\text { formation }\end{array}$ & $\begin{array}{l}\text { Thick, fine to medium and coarse sand with } \\
\text { sandy clays and shalely limestone }\end{array}$ \\
\cline { 3 - 4 } & $\begin{array}{l}\text { Cretaceous } \\
\text { (c) Imo shale }\end{array}$ & $\begin{array}{l}\text { Very thick shale with lenticular sands. This is } \\
\text { essentially an aquiclude }\end{array}$ \\
\hline 5 & Beposits & $\begin{array}{l}\text { False- bedded sandstone. } \\
\text { Fugar sandstone }\end{array}$ & Thick moderately permeable aquifers \\
\hline ment complex & $\begin{array}{l}\text { Meta sediments, } \\
\text { migmatites, gneisses, and } \\
\text { granites }\end{array}$ & $\begin{array}{l}\text { Isolated aquifers in weathered zones, joints and } \\
\text { faults. Aquifer has low to moderate yields. }\end{array}$ \\
\hline
\end{tabular}


From Table 1, the results indicated that the alluvium deposits does not present important aquifers in Edo State due to the isolated minor sand lenses it contains and that of the basement complex has low to moderate yield.

Table 2 show the location where Electrical Resistivity tests were conducted.

Table 2: Electrical resistivity data in the quaternary sediments

\begin{tabular}{|l|l|l|}
\hline S/N & Location & $\begin{array}{l}\text { Depth to top of Saturated Zone } \\
\text { (inferred) (m) }\end{array}$ \\
\hline 1 & Oghada & 65 \\
\hline 2 & Uhie & 71.20 \\
\hline 3 & Umelu & 75.0 \\
\hline 4 & Iguododo & 96 \\
\hline 5 & Oghede & 83 \\
\hline 6 & Evboesi & 73 \\
\hline 7 & Evbuekabua & 93 \\
\hline 8 & Evbuekoi & 102 \\
\hline 9 & Ugbineh & 20 \\
\hline
\end{tabular}

Electrical resistivity carried out at Ugbineh was used as a case study for Quaternary sediments. The resistivity data are presented in Table $3 a$ and $3 b$ while the curve is in Figure 2.

Table 3a: Resistivity data for Ugbineh

\begin{tabular}{|l|l|l|l|}
\hline \multicolumn{2}{|l|}{ Synthetic Difference Spacing (m) } & $\begin{array}{l}\text { Array } \\
\text { Geometric } \\
\text { Factor (K) }\end{array}$ & $\begin{array}{l}\text { Apparent } \\
\text { Resistivity } \\
\text { (Roa) (Ohm-m) }\end{array}$ \\
\hline AB/2 & MN & 5.8905 & 301.76 \\
\hline 1 & 0.5 & 13.744 & 204.7 \\
\hline 1.5 & 0.5 & 24.74 & 202.1 \\
\hline 2 & 0.5 & 56.156 & 248.93 \\
\hline 3 & 0.5 & 126.84 & 317.58 \\
\hline 4.5 & 0.5 & 307.48 & 338.75 \\
\hline 7 & 0.5 & 627.93 & 327.26 \\
\hline 10 & 0.5 & 659.73 & 373.12 \\
\hline 14.5 & 1 & 1451 & 453.8 \\
\hline 21.5 & 1 & 1607 & 797.59 \\
\hline 32 & 2 & 1384 & 1750 \\
\hline 47 & 5 & 3134 & 1400 \\
\hline 100 & 10 & 3519 & 1739 \\
\hline 150 & 20 & 7587 & 1400 \\
\hline 220 & 20 & 6395 & 2493 \\
\hline 320 & 50 & & \\
\hline & & & \\
\hline
\end{tabular}

Table 3b: Geoelectric parameters and inferred lithology for Ugbineh

\begin{tabular}{|l|l|l|l|l|}
\hline Layer & Thickness $(\mathrm{m})$ & Depth $(\mathrm{m})$ & Resistivity(ohm-m) & Lithology \\
\hline 1 & 0.5897 & 0.5897 & 335.4 & Lateritic Topsoil \\
\hline 2 & 0.6154 & 1.205 & 109.2 & Sandy Sub- soil \\
\hline 3 & 1.203 & 2.408 & 580.2 & Sandy Clay \\
\hline 4 & 2.521 & 4.93 & 183.2 & Clayey Formation \\
\hline 5 & 4.794 & 9.723 & 634.75842 & Clay stone (Dry) \\
\hline 6 & 10.4 & 20.12 & 1456 & Sandy Clay \\
\hline 7 & 61.29 & 81.41 & 3188 & Sandy Clay \\
\hline 8 & 57.36 & 138.77 & 1453 & Sand (Aquifer) \\
\hline 9 & Undefined & Undefined & 537.1 & Sandstone (Aquifer) \\
\hline
\end{tabular}

Results in Table 3a and $3 \mathrm{~b}$ were interpreted, using sounding curves as shown in Figure 2. Note that $\mathrm{AB}$ is the outer (current) electrode spacing and $\mathrm{MN}$ is the inner (potential) electrode spacing. 


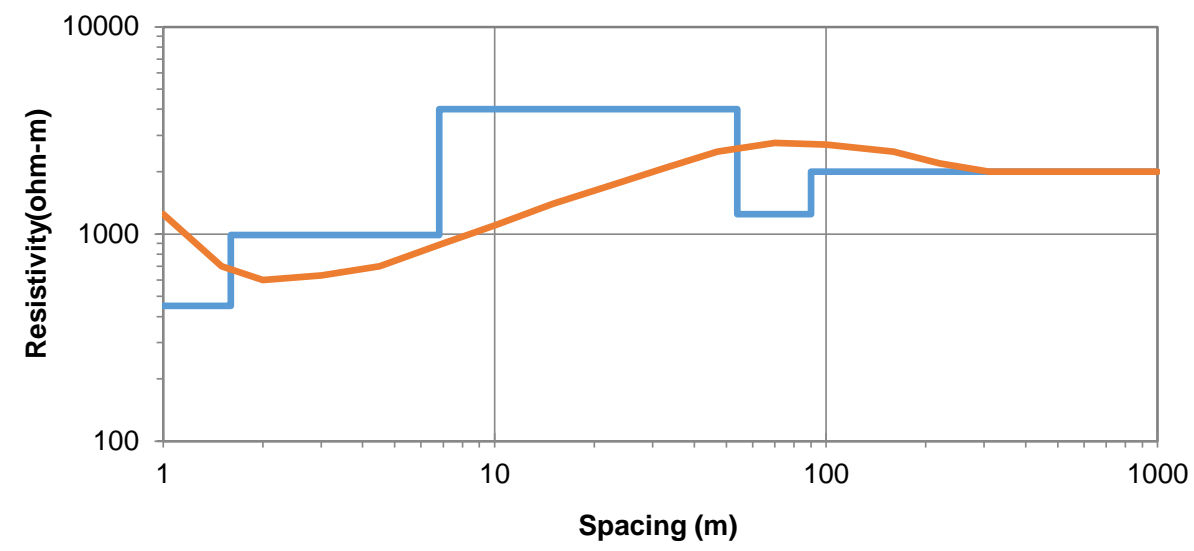

Figure 2: Resistivity curve for Ugbineh

Nine geo-electric layers were revealed for Ugbineh as indicated in Table $3 \mathrm{~b}$ with the top of saturated sand layer at $20.12 \mathrm{~m}$ deep, while the depth to the top of the aquifer was $138 \mathrm{~m}$ and that of the base, undefined. This indicates that the groundwater may tend to be ferruginised (i.e. the groundwater may contain a sizable amount of $\mathrm{Fe}^{2+}$ ). This result is in accordance with that obtained from the study conducted by Ako and Olorunfemi (1989), which show that one of the peculiarities of deep aquifer is that the groundwater tends to be ferruginised.

Electrical resistivity data in the tertiary sediments are presented in Table 4.

Table 4: Electrical resistivity data in the tertiary sediments

\begin{tabular}{|l|l|l|}
\hline S/N & Location & $\begin{array}{l}\text { Resistivity } \\
\text { (Ohm-m) }\end{array}$ \\
\hline 1 & Ehor & 200 \\
\hline 2 & Ekpoma & 264 \\
\hline 3 & Ubiaja & 220 \\
\hline 4 & Eguaholor & 174 \\
\hline 5 & Odiguetue & 322 \\
\hline
\end{tabular}

Electrical resistivity for Ekpoma was used as a case study for Tertiary sediments. The resistivity data are shown in Tables 5a and 5b.

Table 5a: Resistivity data for Ekpoma (VES1)

\begin{tabular}{|c|c|c|c|c|c|}
\hline \multirow{2}{*}{$\mathrm{S} / \mathrm{N}$} & \multicolumn{2}{|c|}{ Synthetic Difference Spacing (m) } & \multirow{2}{*}{$\begin{array}{l}\text { Data Resistivity } \\
(\mathrm{Ohm}-\mathrm{m})\end{array}$} & \multirow{2}{*}{$\begin{array}{l}\text { Synthetic } \\
\text { Resistivity (Ohm- } \\
\text { m) }\end{array}$} & \multirow{2}{*}{$\begin{array}{l}\text { Potential Difference } \\
\text { (V) }\end{array}$} \\
\hline & $\mathrm{AB} / 2$ & MN & & & \\
\hline 1 & 2.00 & 0.500 & 158.0 & 154.60 & 2.11 \\
\hline 2 & 6.00 & 1.00 & 158.0 & 173.1 & -9.55 \\
\hline 3 & 8.00 & 1.00 & 181.0 & 178.9 & 1.10 \\
\hline 4 & 12.00 & 1.00 & 204.0 & 188.2 & 7.70 \\
\hline 5 & 15.00 & 2.00 & 212.0 & 194.8 & 8.07 \\
\hline 6 & 25.00 & 2.00 & 240.0 & 223.2 & 6.99 \\
\hline 7 & 32.00 & 2.00 & 241.0 & 251.4 & -4.31 \\
\hline 8 & 40.00 & 5.00 & 251.0 & 291.1 & -15.98 \\
\hline 9 & 60.00 & 5.00 & 360.0 & 410.7 & -14.10 \\
\hline 10 & 100.0 & 10.00 & 656.0 & 670.7 & -2.25 \\
\hline 11 & 150.0 & 10.00 & 1056.0 & 989.7 & 989.7 \\
\hline 12 & 200.0 & 10.00 & 1360.0 & 1296.1 & 6.27 \\
\hline 13 & 250.0 & 15.00 & 1750 & 1588.8 & 9.21 \\
\hline 14 & 300.0 & 15.00 & 2100 & 1866.7 & 11.10 \\
\hline 15 & 350.0 & 15.00 & 2411 & 2129.3 & 11.68 \\
\hline 16 & 400 & 15.00 & 2836.0 & 2376.2 & 16.21 \\
\hline 17 & 450.0 & 15.00 & 2513.0 & 2607.3 & -3.75 \\
\hline 18 & 500.0 & 20.00 & 2237.0 & 2822.5 & -26.17 \\
\hline
\end{tabular}


Table 5b: Geoelectric parameters and inferred lithology at Ekopma [VES1]

\begin{tabular}{|l|l|l|l|}
\hline Layer No & $\begin{array}{l}\text { Apparent Resistivity } \\
(\mathrm{Ohm}-\mathrm{m})\end{array}$ & Thickness (m) & Lithology \\
\hline 1 & 150 & 1.56 & Topsoil \\
\hline 2 & 181 & 2.83 & Sub topsoil \\
\hline 3 & 195 & 23.23 & Clayey layer \\
\hline 4 & 29305 & 236.1 & Dry/resistive sandy layer \\
\hline 5 & 492 & - & Saturated sand layer \\
\hline
\end{tabular}

Results in Table 5a and 5b were interpreted, using sounding curve as shown in Figure 3.

(a)

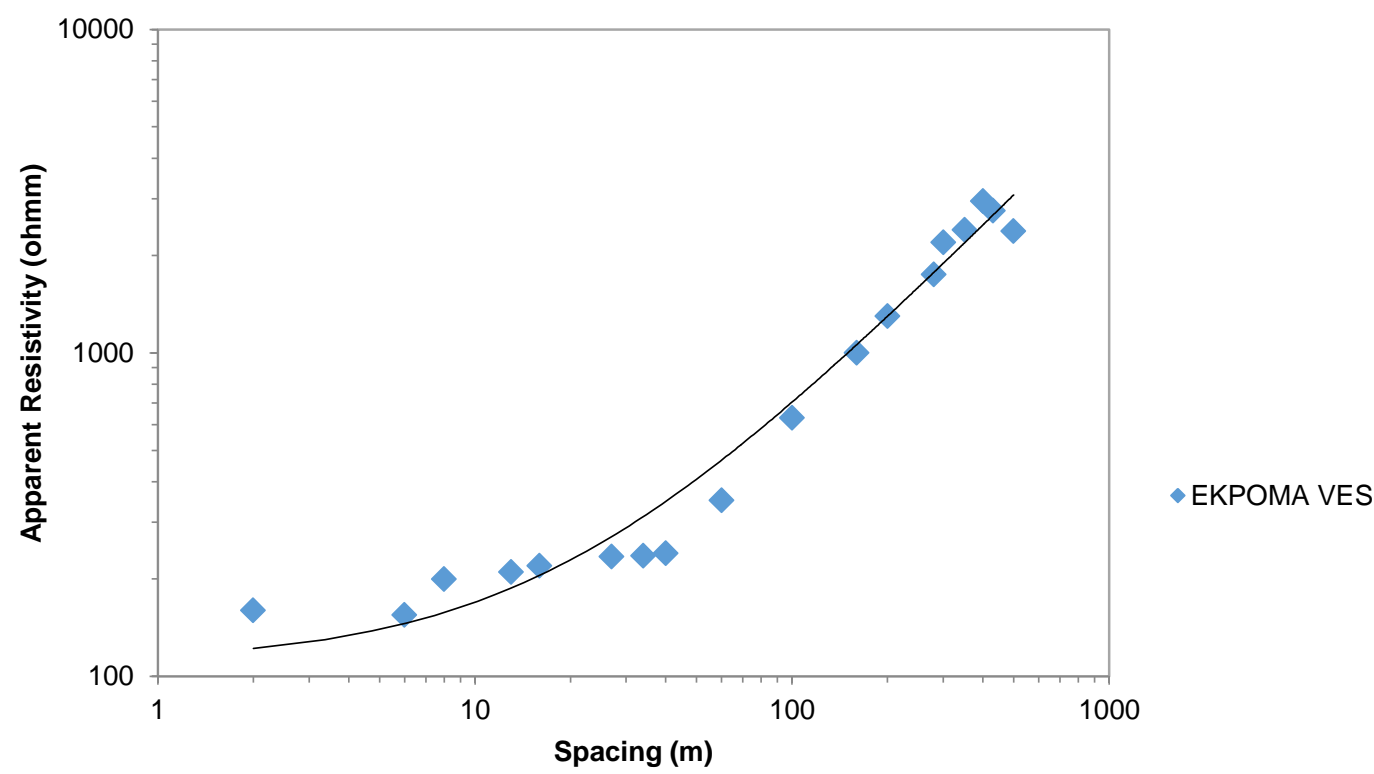

(b)

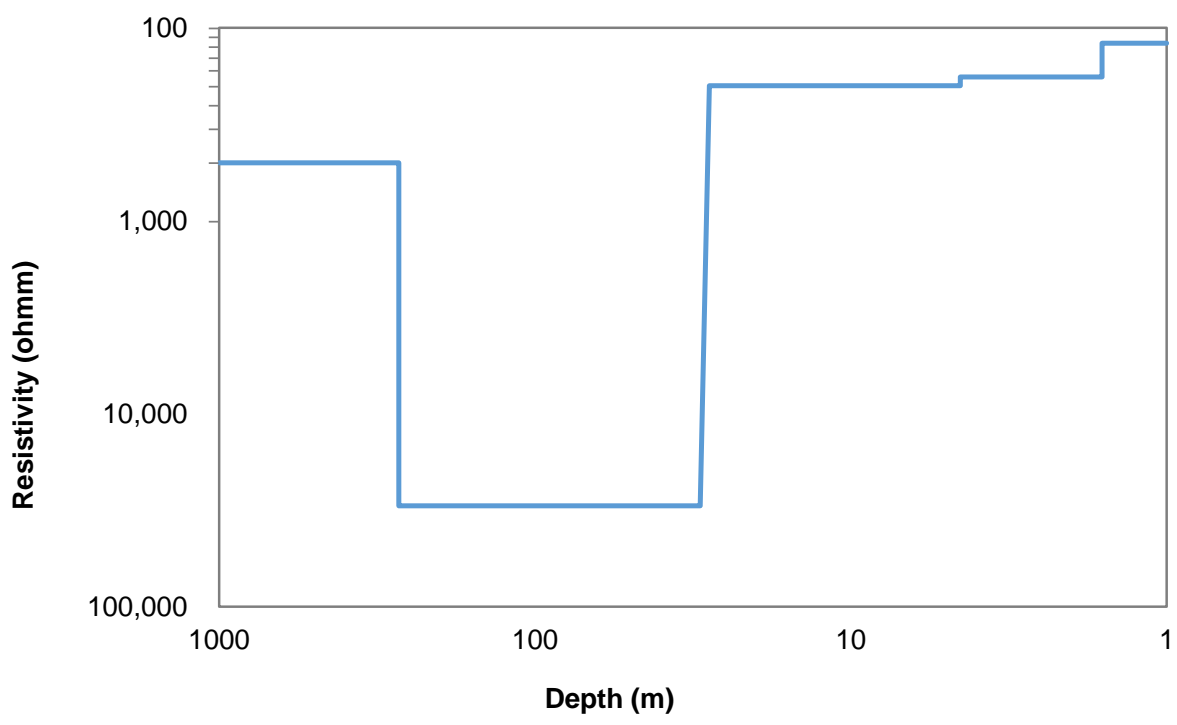

Figure 3: Resistivity curve for Ekpoma (VES1)

Table 5a and 5b show the interpreted VES data as well as the inferred lithology for Ekopma. This indicated that five geo-electric layers were revealed for Ekpoma with the fifth layer indicating the aquifer (i.e. saturated sand layer).

Table 6 presents the electrical resistivity data in cretaceous sediments. 
Table 6: Electrical resistivity data in cretaceous sediments

\begin{tabular}{|l|l|l|}
\hline S/N & Location & $\begin{array}{l}\text { Data Resistivity } \\
(\text { Ohm-m) }\end{array}$ \\
\hline 1 & Afuze & 129 \\
\hline 2 & Usen & 102 \\
\hline 3 & Ugbogui & 65 \\
\hline 4 & Uzebba & 163 \\
\hline 5 & Agennobode & 98 \\
\hline 6 & Auchi & 150 \\
\hline 7 & Ovbiomu & 150 \\
\hline 8 & Iyakpi & 195 \\
\hline 9 & Egori & 254 \\
\hline
\end{tabular}

In the case of cretaceous sediments, electrical resistivity at Auchi is presented as shown in Tables 7a and $7 b$.

Table 7a: Resistivity data for Auchi at VES 2

\begin{tabular}{|l|l|l|l|l|l|}
\hline \multirow{2}{*}{ No } & \multicolumn{2}{|l|}{ Synthetic Difference Spacing $(\mathrm{m})$} & $\begin{array}{l}\text { Data Resistivity } \\
\text { (Ohm-m) }\end{array}$ & $\begin{array}{l}\text { Synthetic Resistivity } \\
(\text { Ohm-m) }\end{array}$ & $\begin{array}{l}\text { Potential } \\
\text { Difference } \\
(\text { V) }\end{array}$ \\
\cline { 2 - 6 } & AB/2 & MN & 636.0 & 608.0 & 4.33 \\
\hline 1 & 1.00 & 0.200 & 572.0 & 623.2 & -8.96 \\
\hline 2 & 1.47 & 0.200 & 700.0 & 668.9 & 4.43 \\
\hline 3 & 2.15 & 0.200 & 800.0 & 783.3 & 2.07 \\
\hline 4 & 3.16 & 0.200 & 947.0 & 984.0 & -3.91 \\
\hline 5 & 4.64 & 0.200 & 1213.0 & 1228.4 & -1.27 \\
\hline 6 & 6.81 & 1.00 & 1400.0 & 1425.9 & -1.85 \\
\hline 7 & 10.00 & 1.00 & 1600.0 & 1466.5 & 8.33 \\
\hline 8 & 14.70 & 1.00 & 1262.0 & 1293.5 & -2.49 \\
\hline 9 & 21.50 & 1.00 & 961.0 & 996.2 & -3.66 \\
\hline 10 & 31.50 & 5.00 & 809.0 & 792.7 & 2.00 \\
\hline 11 & 46.40 & 5.00 & 788.0 & 779.8 & 1.03 \\
\hline 12 & 61.80 & 5.00 & 954.0 & 970.5 & -1.73 \\
\hline 13 & 100.0 & 10.00 & 1153.0 & 1153.9 & -0.0821 \\
\hline 14 & 133.0 & 10.00 & 1304.0 & 1352.0 & -3.68 \\
\hline 15 & 178.0 & 10.00 & 1512.0 & 1507.7 & 0.279 \\
\hline 16 & 237.0 & 10.00 & 1697.0 & 1566.0 & 7.70 \\
\hline 17 & 316,0 & 10.00 & 1433.0 & 1474.0 & -2.86 \\
\hline 18 & 422.0 & 10.00 & 1207.0 & 1222.8 & -1.31 \\
\hline 19 & 562.0 & 10.00 & & & \\
\hline
\end{tabular}

Table 7b: Geo-electric parameters and inferred lithology at Auchi (VES 2)

\begin{tabular}{|l|l|l|l|}
\hline LAYER NO & $\begin{array}{l}\text { Apparent Resistivity } \\
(\text { Ohm-m) }\end{array}$ & Thickness (m) & Lithology \\
\hline 1 & 602 & 1.38 & Topsoil \\
\hline 2 & 227 & 0.3 & Sub topsoil \\
\hline 3 & 4073 & 4.54 & Sandstone layer \\
\hline 4 & 260 & 7.45 & Sandy/clayey layer \\
\hline 5 & 719 & 38.98 & Sandy/Sandstone layer \\
\hline 6 & 5231 & 97.5 & Dry sandy/Sandstone \\
\hline 7 & 155 & $<150$ & Saturated sand layer \\
\hline
\end{tabular}

Results in Table 7a and 7b are interpreted, using sounding curves as shown in Figure 4. 


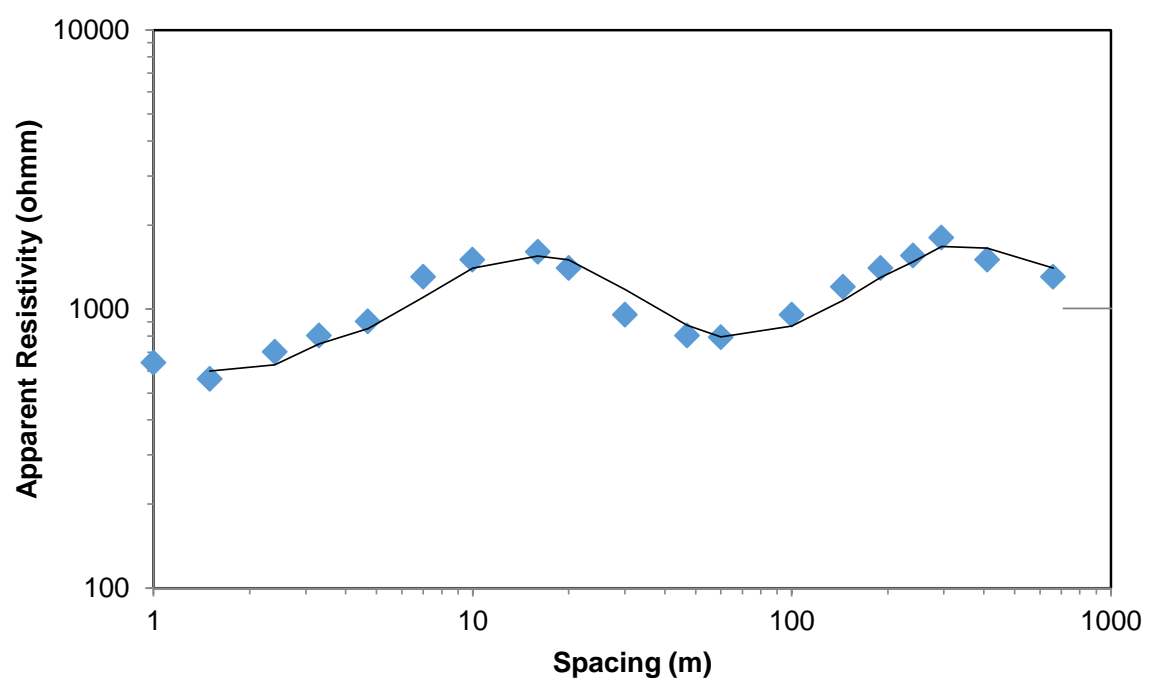

AUCHI VES

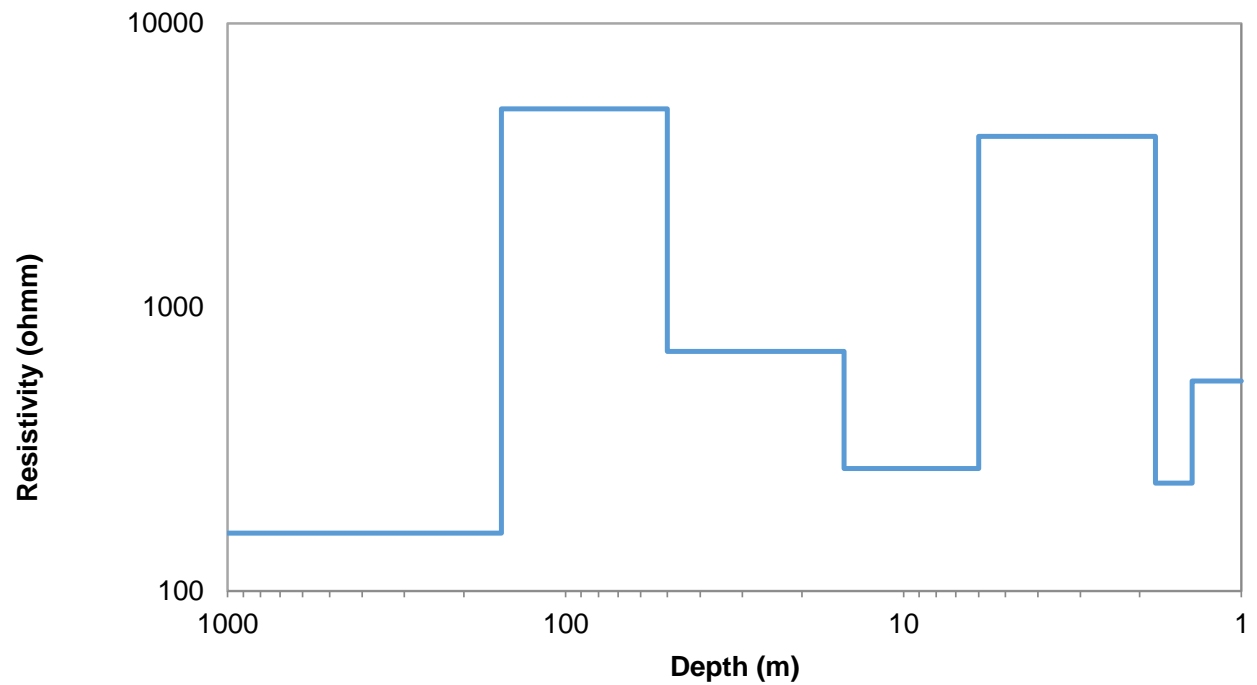

Figure 4: Resistivity curve for Auchi

Interpretation of the resistivity data revealed six geo-electric layers with the top of saturated sandy layer below $150 \mathrm{~m}$ deep as indicated in Table $7 \mathrm{~b}$.

Electrical resistivity data in some selected basement complex locations are summarized in Table 8 . The data presented in Table 8 show the erratic nature of aquifers in the basement complex rocks. Thicknesses of overburden and weathered rocks vary widely from location to location. Data obtained from Oluma-Otuo and Iyeu-Otuo which is barely $2 \mathrm{~km}$ apart revealed a great deal of variation. At Ukhuse-Oke, weathered rocks are absent and the overburden provides the only aquifer in the location. 
Table 8: Electrical resistivity data in the basement complex

\begin{tabular}{|l|l|l|}
\hline Location & Thickness (m) of probable aquifer & Inferred Lithology \\
\hline Igarra & 19.52 & Overburden \\
& 33.14 & Weathered Zone \\
& Below $52.66 \mathrm{~m}$ & Fresh basement rock \\
\hline Ikiran-Ile & 7.01 & Overburden \\
& 6.12 & Weathered Zone \\
& Below $13.13 \mathrm{~m}$ & Fresh basement rock \\
\hline Okpilla & 8.09 & Overburden \\
& 33.50 & Weathered Zone \\
& Below $41.59 \mathrm{~m}$ & Fresh basement rock \\
\hline Ugboshi-Ele & 9.17 & Overburden \\
& 8.28 & Weathered Zone \\
& Below $17.45 \mathrm{~m}$ & Fresh basement rock \\
\hline Ukhuse- oke & 34.22 & Overburden \\
& 0 & Weathered Zone \\
& Below $34.22 \mathrm{~m}$ & Fresh basement rock \\
\hline Oluma-Otuo & 4.0 & Overburden \\
& 31.0 & Weathered Zone \\
& Below $35.0 \mathrm{~m}$ & Fresh basement rock \\
\hline Iyeu-Otuo & 5.75 & Overburden \\
& 23.5 & Weathered Zone \\
& Below $29.25 \mathrm{~m}$ & Fresh basement rock \\
\hline
\end{tabular}

The results of the borehole drilled in selected location within the state are presented in Table 9. The groundwater levels show the direct relationship between topography of the borehole location and depth to static water level. The groundwater level is deepest in Ishan Plateau and also has the highest altitude. Ekpoma is on an elevation of about $342 \mathrm{~m}$ above the sea level while the groundwater is 176 $\mathrm{m}$ below ground surface. Away from the Plateau, groundwater rises towards all directions, North, East, West and South. To the North-East of the Plateau, at Idoa, the water level is $96 \mathrm{~m}$ below ground surface and to the South-East at Ogua, the water level below ground surface is $120 \mathrm{~m}$. To the SouthWest at Ehor, the water level is $122 \mathrm{~m}$ below ground surface.

In the Benin Formation, groundwater level is low in Urhonigbe $(7 \mathrm{~m})$ and high in Ekiadolor $(78 \mathrm{~m})$, Aduwawa/Ikpoba Hill $(72 \mathrm{~m})$, Iguobazuwa $(81 \mathrm{~m})$ and Iguiye $(70 \mathrm{~m})$. These are areas with the highest elevation in the Benin Formation. In Southern part of the Benin Formation, groundwater level is low in Ologbo $(7 \mathrm{~m})$ and a bit high in Abudu $(32 \mathrm{~m})$, Iyanomo $(17 \mathrm{~m})$ which also follows the pattern of topography.

In the Creteceous sediments, groundwater levels are deepest in Ogbona (190 m), Fugar (133 m) and Afuze $(58 \mathrm{~m})$. It was observed that in the Cretaceous, some boreholes are either semi-artesian or fully artesian. The boreholes at Sabongidda-Ora are fully artesian where groundwater flows freely out of the borehole to as much as 2-3 m above ground surface. It was also found that a borehole drilled at Sabongidda-Ora/Afuze road junction has been flowing freely since it was drilled (more than 2 years ago). At Uzebba and parts of Auchi, ground waters are semi-artesian.

Figure 5 show groundwater level of Edo State (3-Dimension). The map was plotted using the groundwater levels obtained from the borehole data in some selected areas of Edo State (see Table 9). The occurrence of groundwater in the Basement Complex areas does not lead to the plotting of the groundwater contour map. This is because the aquifers are localized and rarely have hydraulic contact with one another. For this reason, the basement complex areas of the state were not covered by groundwater contours. 
Table 9: Summary of borehole data at selected area in Edo State

\begin{tabular}{|c|c|c|c|c|c|c|c|c|}
\hline $\mathrm{S} / \mathrm{N}$ & $\begin{array}{l}\text { Borehole } \\
\text { Locality }\end{array}$ & $\begin{array}{l}\text { Elevation } \\
\text { (ASL) } \\
(\mathrm{m})\end{array}$ & $\begin{array}{l}\text { Total } \\
\text { Depth } \\
(\mathrm{m})\end{array}$ & $\begin{array}{l}\text { Final } \\
\text { Water } \\
\text { Level (m) }\end{array}$ & $\begin{array}{l}\text { Water } \\
\text { Level } \\
\text { (ASL) } \\
(\mathrm{m})\end{array}$ & $\begin{array}{l}\text { Yeild } \\
\left(\mathrm{m}^{3} / \mathrm{h}\right)\end{array}$ & $\begin{array}{l}\text { Draw } \\
\text { Down }(\mathrm{m})\end{array}$ & $\begin{array}{l}\text { Specific } \\
\text { Capacity } \\
\left(\mathrm{m}^{3} / \mathrm{h} / \mathrm{m}\right)\end{array}$ \\
\hline 1 & $\begin{array}{l}\text { Aduwawa/ } \\
\text { Ikpoba Hill }\end{array}$ & 102 & 148.3 & 72 & 40 & 136 & 4.05 & 33.6 \\
\hline 2 & $\begin{array}{l}\text { Esigie } \\
\text { St. Emmanuel }\end{array}$ & 90 & 111.5 & 56.07 & 33.9 & 109.8 & 3.1 & 35.4 \\
\hline 3 & Iyaro & 93 & 114.3 & 52.6 & 40.4 & 71.0 & 1.87 & 37.9 \\
\hline 4 & New Benin & 92 & 143.3 & 54.5 & 37.5 & - & - & - \\
\hline 5 & Guiness & 78 & 87 & 43.6 & 34.4 & 108.3 & 3.1 & 34.9 \\
\hline 6 & Edo Textile Mill & 62 & 102 & 55.5 & 6.5 & 67.0 & 7.5 & 8.9 \\
\hline 7 & Obayantor & 59 & 85.7 & 34.3 & 24.7 & 45.8 & 2.8 & 16.4 \\
\hline 8 & Iyanomo & 31 & 106.5 & 17.00 & 14.00 & 23.8 & 4.7 & 5.01 \\
\hline 9 & Abudu & 59 & 75.4 & 31.5 & 27.5 & 76.6 & 3.1 & 24.7 \\
\hline 10 & Ologbo & 10 & 98 & 6.5 & 3.5 & 43.1 & 4.0 & 10.8 \\
\hline 11 & Urhonigbe & 41 & 57 & 7.00 & 3.4 & 41.6 & 4.0 & 10.3 \\
\hline 12 & Okada Dry & 87 & 114.0 & 51.7 & 35.3 & 79.5 & 3.1 & 25.6 \\
\hline 13 & Ugoneki & 95 & 95.3 & 56.7 & 38.3 & 17.2 & 1.6 & 10.8 \\
\hline 14 & Iguobazuwa & 138 & 117.8 & 81.0 & 57 & 40.1 & 3.7 & 10.8 \\
\hline 15 & Iguiye & 125 & 110.6 & 69.8 & 55.2 & 41.4 & 5.0 & 8.3 \\
\hline 16 & Ogan & 155.7 & 160.1 & 101 & 54.7 & 30.1 & 2.5 & 12 \\
\hline 17 & Ugo & 98 & 155.7 & 63.6 & 34.4 & 55.1 & 1.2 & 46 \\
\hline 18 & Okhuo & - & 141.7 & 18.7 & - & 45.4 & 3.1 & 14.6 \\
\hline 19 & Ogba & 64 & 81 & 3.1 & 60.9 & 76.7 & 4.4 & 17.4 \\
\hline 20 & Iguovbiobo & 109 & 79 & 64 & 45 & 52.2 & 1.6 & 32.6 \\
\hline 21 & Ehor & 260 & 204.7 & 122 & 138 & 45.8 & 2.5 & 18.3 \\
\hline 22 & Ugieghudu & 247 & 208.7 & 119 & 128 & - & - & - \\
\hline 23 & Iruekpen & 337 & - & 171 & 166 & - & - & - \\
\hline 24 & Igieduma & 259 & - & 122 & 137 & - & - & - \\
\hline 25 & Ekpoma & 342 & 350 & 171 & 171 & - & - & - \\
\hline 26 & Evboerhen & 214 & - & 91 & 123 & - & - & - \\
\hline 27 & Idoa & 238 & 138 & 96 & 142 & - & - & - \\
\hline 28 & Ogua & 250 & 200 & 120 & 130 & - & - & - \\
\hline 29 & Igbanke & 224 & 220 & 119.6 & 104.4 & 37.2 & 7.2 & 5.2 \\
\hline 30 & Ugboha & 146 & 168.5 & 86 & 60 & 37.9 & 20 & 1.9 \\
\hline 31 & Eguaholor & 187 & 213 & 112 & 77 & 13.2 & 14.6 & 0.9 \\
\hline 32 & Afuze & 88 & 140.8 & 57.6 & 30.4 & 55.1 & 3.7 & 14.9 \\
\hline 33 & Ihievbe & - & 124.6 & 43.6 & - & 9.6 & 21.8 & 0.44 \\
\hline 34 & Auchi & 224 & 203 & 96.6 & 126 & 41.3 & 31.1 & 1.3 \\
\hline 35 & Agenebode & 79 & 169 & 114 & -35 & 40 & 7.2 & 5.5 \\
\hline 36 & Fugar & 218 & 175 & 133 & 95 & 26.5 & 1.6 & 16.6 \\
\hline 37 & Uzebba & - & 127 & \multicolumn{2}{|l|}{ Artesian } & 76.6 & 11.8 & 6.5 \\
\hline 38 & Sabongidda-Ora & 94 & 141 & \multicolumn{2}{|l|}{ Artesian } & 76.6 & 8.7 & 8.8 \\
\hline 39 & Ogbona & 249 & 221 & 190 & 59 & 56.8 & 12.5 & 4.5 \\
\hline 40 & Oben & - & 94 & 31 & - & 20 & 6.2 & 3.2 \\
\hline 41 & Sobe & - & 148 & 43 & - & 15.5 & 31.7 & 0.5 \\
\hline 42 & $\begin{array}{l}\text { Ekenwan Army } \\
\text { Barracks }\end{array}$ & 58 & 140 & 40 & 18 & - & - & - \\
\hline 43 & $\begin{array}{l}\text { Amedokhian } \\
\text { (Uromi) }\end{array}$ & - & 296 & 199 & - & - & - & - \\
\hline 44 & Udo & 120 & 1.31 & 72 & 48 & 26.5 & 6.2 & 4.3 \\
\hline 45 & Ekiadolor & - & 162 & 78 & - & - & - & - \\
\hline
\end{tabular}




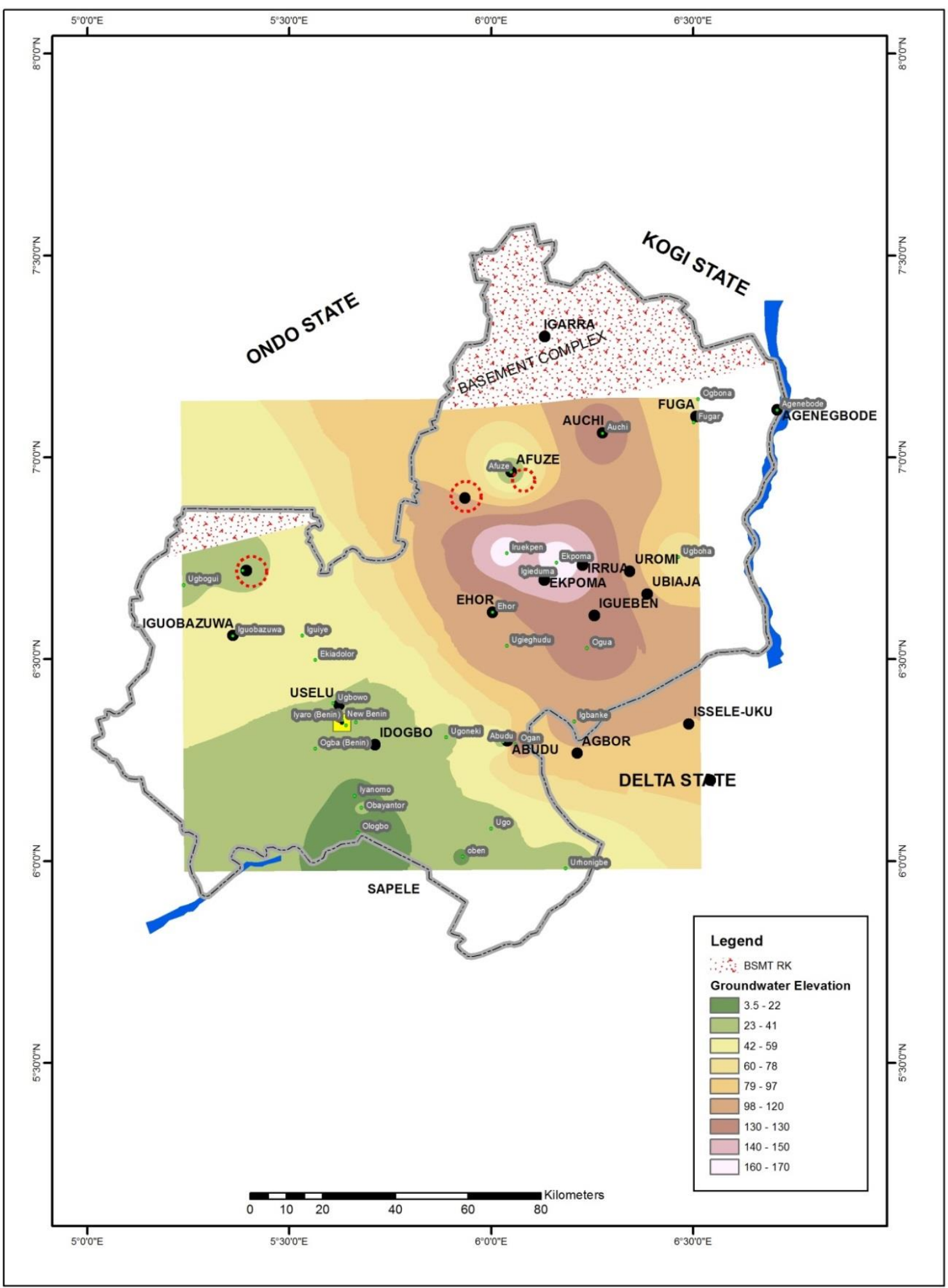

Figure 5: Groundwater level map of Edo State in 3-Dimension

\subsection{Conclusion}

The mapping of aquifers in Edo State has led to the collection, collation and analysis of relevant information and data required in the successful development of groundwater in the state. The study has revealed that drilling should not be done on a trial and error basis, but has to be guided by available geological and hydrogeological data. Therefore, it is necessary to continue to improve on the data base for groundwater development in the state. To achieve this, it is recommended that the State Government should compel all groundwater developers to lodge their data with the State Urban Water 
Board. The Benin Owina River Basin Development Authority should also be encouraged to maintain a data bank for groundwater resources.

\section{References}

Ako B. D. and Olorunfemi, M. O. (1989). Geoelectrical Survey for Groundwater in the Newer Basals of Vom, Plateau State. Journal of Mining and Geol., 10, pp. 23-30.

Alabi, A. A., Bello, R., Ogungbe, A. S. and Oyerinde, H. O. (2010). Determination of Groundwater Potential in Lagos State University, Ojo; using geoelectric methods (Vertical electrical sounding and horizontal profiling). Report Opinion, 24, pp. 68-75.

Anomohanran, O. (2011a). Underground Water Exploration of Oleh, Nigeria Using the Electrical Resistivity Method. Scientific Res. Essays, 6, pp. 4295-4300.

Anomohanran, O. (2011b). Determination of Groundwater Potential in Asaba, Nigeria Using Surface Geoelectric Sounding. Int. J. Physical Sci., 6, pp. 7651-7656.

Benin Kingdom/ Edo State Weather, (2018), [Online], Available: http://www.edoworld.net/Edotourismweather.html [Accessed: $14^{\text {th }}$ September, 2018].

Egbai, J. C. (2012). Geoelectric Evaluation of Groundwater Potential in the Sedimentary Region of Abavo, Delta State and Urhonigbe, Edo State, Nigeria. International Journal of Research and Review in Sciences, 10(3), pp. 491.

Egbai, J. C., Efeya, P. and Iserhien-Emekeme, R. E. (2015). Geoelectric Evaluation of Aquifer Vulnerability in Igbanke, Orhionmwon Local Government Area of Edo State, Nigeria. International Journal of Science, Environment and Technology, 4(3), pp. 701-715.

Emenike, E. A. (2000). Geophysical Exploration for Groundwater in a Sedimentary Envrionment: A case study from Nanka over Nanka Formation in Anambra Basin, Southeastern, Nigeria. Global Jour. of Pure and Applied Sciences. 7(1), pp. 97-110.

Kogbe, C.A. (1989). Geology of Nigeria, $1^{\text {st }}$ Edition, Rock View (Nig.) Ltd., Plot 1234, Zaramaganda, Km.8, Yakubu Gowon Way, Jos, Nigeria.

Map of Edo State (2016), [Online], Available: https://www.nigeriagalleria.com/Nigeria/States_Nigeria/Edo/Edo_State.html [Accessed: 26th September, 2016].

Oyedele, K. F. (2001). Geo-Electric Investigation of Groundwater Resources at Onibode Area, Near Abeokuta South-West Nigeria, pp. 501-504.

Peter, O. O. (2013). Groundwater Potential Evaluation and Aquifer Characterization Using Resistivity Method in Southern Obubra, Southeastern Nigeria. International Journal of Environmental Sciences, 4, pp. 96-105.

Stockmarr, J. and Thomsen, R. (2012). Water Supple in Denmark. The Danish Action Plan for Promotion of Eco-efficient Technologies - Danish Lessons. Danish Ministry of the Environment. 